\title{
PENERAPAN MODEL PEMBELAJARAN COOPERATIVE SCRIPT DALAM KEMAMPUAN MEMBACA BAHASA JERMAN SISWA KELAS XI IPA MAN 1 MAKASSAR
}

\author{
Mariona $^{1}$ dan Abd. Kasim Ahmad ${ }^{2}$ \\ Fakultas Bahasa dan Sastra, Universitas Negeri Makassar \\ E-mail': marionadali@gmail.com
}

\begin{abstract}
ABSTRAK
Penelitian ini merupakan penelitian tindakan kelas yang dilaksanakan dengan 2 siklus. Data penelitian ini terdiri atas dua jenis, yaitu: data kuantitatif dan data kualitatif. Data kualitatif diperoleh melalui observasi sedangkan data kuantitatif diperoleh melalui hasil tes kemampuan membaca memahami siklus I dan siklus II. Data dianalisis dengan menggunakan teknik persentase. Hasil penelitian menunjukkan bahwa kemampuan membaca memahami persentase nilai yang diperoleh siswa pada siklus I mencapai $64,72 \%$, dan siklus II mencapai $93,10 \%$. Hasil ini menunjukkan bahwa penerapan model pembelajaran Cooperative Script meningkatkan kemampuan membaca bahasa Jerman siswa Kelas XI MAN 1 Makassar.
\end{abstract}

\section{Kata Kunci : Cooperative Script, Kemampuan Membaca, dan Bahasa Jerman}

\begin{abstract}
This research is a classroom action research conducted with 2 cycles. This research data consists of two types, namely: quantitative data and qualitative data. Qualitative data obtained through observation while the quantitative data obtained through the reading ability test to understand cycle I and cycle II. Data were analyzed using percentage technique. The results showed that the ability to read understanding the percentage of the value obtained by students in the first cycle reached $64.72 \%$, and cycle II reached $93.10 \%$. This result shows that the implementation of Cooperative Script learning model improves the reading ability of German students of Class XI MAN 1 Makassar.
\end{abstract}

Keywords: Cooperative Script, Reading Skill, and German Language.

\section{PENDAHULUAN}

Salah satu kemampuan dasar yang
dapat meningkatkan kompetensi dan
wawasan bahasa seseorang adalah
kemampuan membaca (Leseverstehen).
Kemampuan membaca sebagai salah satu
yang difokuskan pada pemahaman seseorang

terhadap bacaan yang telahdibaca, khususnya bahasa Jerman. Kurangnya minat membaca, siswa kurang membaca buku bahasa Jerman, siswa kurang mempunyai buku bahasa Jerman dan siswa kurang memahami suatu bacaan. Hal tersebut merupakan faktor yang dialami siswa kurang berminat dalam 
pembelajaran bahasa Jerman (Nurmiati, 2017).

Berdasarkan hasil observasi yang telah dilakukan di Madrasah Aliyah Negeri (MAN) 1 Makassar pada tanggal 22 Juli 2016 pada pukul 10.30 - 12.00 diperoleh informasi bahwa siswa masih mengalami kesulitan dalam memahami teks bahasa Jerman. Kesulitan tersebut diduga karena guru tidak menerapkan model pembelajaran yang sesuai dengan materi yang diajarkan dan kurangnya latihan-latihan yang dilakukan siswa.

Rendahnya kemampuan siswa dalam memahami bacaan bahasa Jerman didukung oleh hasil penelitian yang telah dilakukan oleh Muslim (2012) menunjukkan bahwa kemampuan membaca teks bahasa Jerman siswa kelas XI IPA SMA Negeri 2 Bonto tiro tergolong rendah, $(38,24 \%)$. Hasil penelitian Sugiarni (2008) menunjukkan pula rendahnya kemampuan membaca teks bahasa Jerman siswa SMA Negeri 3 Makassar masih rendah yakni 48,6\%. Widyastuti (2013) dalam hasil penelitiannya menunjukkan bahwa kemampuan membaca teks Bahasa Jerman siswa kelas XI IPA SMA Negeri 1 Makassar masih rendah $(52,94 \%)$.

\section{COOPERATIVE SCRIPT}

$\begin{array}{llr}\text { Ada beberapa tipe } & \text { dalam } \\ \text { pembelajaran kooperatif yang } & \text { dapat } \\ \text { digunakan oleh guru dalam } & \text { proses } \\ \text { pembelajaran. Salah satunya adalah } & \text { model } \\ \text { pembelajaran coverative script. } & \text { Model } \\ \text { pembelajaran Cooperative Script, siswa akan } \\ \text { terlatih mengembangkan ide-idenya sehingga } \\ \text { siswa dapat mengonstruksi sendiri } \\ \text { pengetahuannya. Model ini juga }\end{array}$

akanmelatihaktivitas belajar sehingga setiap siswa mempunyai tugas dalam proses pembelajaran berlangsung.

Proses siswa bekerjasama untuk berpasangan dan bergantian untuk mendefinisikan bagian inti materi yang akan dipelajari.Pendapat tersebutsenada menurut Suprijono, (2014:126) "cooperative script merupakan metode belajar di mana siswa bekerja berpasangan dan bergantian secara lisan mengikhtisarkan, bagian-bagian dari materi yang dipelajari”.

Selanjutnya, Huda (2014:213) juga menyatakan model pembelajaran cooperative script adalah " salah satu strategi pembelajaran bagi siswa bekerja secara berpasangan dan bergantian materi yang dipelajari". Senada dengan pendapat di atas Andayani (2015:242) juga memaparkan bahwa model pembelajaran cooperative script adalah " metode belajar yang diterapkan dengan cara siswa bekerja secara berpasangan dan bergantian secara lisan dalam mengikhtisarkan bagian materi-materi yang dipelajari.".

Berdasarkan beberapa pendapat diatas dapat disimpulkan bahwa model pembelajaran Cooperative Script adalah kerjasama dalam belajar dan membuat ringkasan atau mengikhtisarkan suatu ide pokok materi yang sedang dipelajari, selain itu siswa belajar menghargai pendapat pasangannya.

Adapun langkah-langkah penerapan Cooperative Scriptmenurut Andayani (2015:242) yaitu (a) guru membagi siswa untuk berpasangan, (b) guru membagikan wacana/materi tiap siswa untuk dibaca dan membuat ringkasan.siswa yang sudah 
mengerti dapat menjelaskan pada anggota lainnya sampai semua anggota dalam kelompok itu mengerti, (b) guru memberikan kuis/pertanyaan kepada seluruh siswa, siswa tidak boleh saling membantu, (c) memberi evaluasi, (d) guru bersama siswa menyusun simpulan bersama-sama".

Pendapat mengenai langkah-langkah model pembelajaran Cooperative Script yang juga dikemukakan oleh Huda(2014: 213-214) dan senada dengan pendapat menurut Suprijono (2012:126-127) pada intinya sama yang menjelaskan bahwa langkah-langkah dalam model pembelajaran Cooperative tipe Script yaitu:“(1) guru membagi siswa kedalam kelompok-kelompok berpasangan, (2) guru membagi wacana/materi tiap siswa untuk dibaca dan membuat ringkasan, (3) Guru dan siswa menetapkan siapa yang pertama berperan sebagai pembicara dan siapayang berperan sebagai pendengar, (4) Pembicara membacakan ringkasan selengkap mungkin, dengan memasukkan ide-ide pokok dalam ringkasannya, (5) Bertukar peran, semula sebagai pembaca ditukarmenjadi pendengar dan sebaliknya. (6) Kesimpulan dibuat siswa dengan guru (7) Penutup".

\section{KEMAMPUAN MEMBACA}

Membaca adalah salah satu keterampilan berbahasa yang sangat penting bagi setiap orang yang belajar bahasa. Membaca dapat dimaknai sebagai suatu proses melihat serta memahami isi dari apa yang tertulis atau informasi berupa tulisan maupun gambar. Menurut Iskandarwassid dan Sunendar (2011:247) mengatakan bahwa "kemampuan membaca merupakan sebuah tes keterampilan berbahasa yang biasa dilakukan dalam pengajaran bahasa, baik dalam pengajaran bahasa pertama maupu bahasa kedua (asing)".

Senada dengan pendapat tersebut Tarigan (2008: 11) menyatakan bahwa kemapuan membaca merupakan" suatu kemampuan untuk menghubungkan tandatanda hitam di atas kertas yaitu gambargambar berpola tersebut dengan bahasa". Selanjutnya, Khoiriyah (2008: 3) mengatakan bahwa kemampuan membaca merupakan “ kecakapan yang harus mdikuasai seorang anak, karena kemampuan ini adalah syarat utama memasuki jenjang pendidikan formal". Berdasarkan beberapa pendapat diatas, dapat disimpulkan bahwa kemampuan membaca suatu proses kesanggupan seseorang anak mampu menguasai melalui pengajaran bahasa yang ditempuh dengan melalui tahap atau teknik menjadi syarat untuk masuk jenjang pendidikan dengan membaca.

\section{METODE PENELITIAN}

Penelitian ini dilaksanakan di
Madrasah Aliyah Negeri (MAN) 1
Makassar, bertempat di Jl, Tala Salapang No.
46. Subjek penelitian ini adalah siswa kelas XI Bahasa Jerman MAN 1 Makassar yang berjumlah 33 orang siswa pada semester genap 2016/2017 dengan fokus penelitian adalah kemampuan membaca dengan menerapkan model pembelajaran cooperative script.

Penelitian ini adalah Penelitian Tindakan Kelas (actions research) yang terdiri atas empat kegiatan utama yaitu (1) perencanaan (plan), (2) pelaksanaan (action), 
(3) pengamatan (observation), dan

refleksi (reflection). Adapun model penelitian tindakan kelas yang digunakan dalam penelitian ini mengacu pada model Hopkins. Setiap siklus meliputi; perencanaan , pelaksanaan tindakan, pengamatan, dan refleksi. Adapun penelitian ini direncanakan 2 siklus.Siklus I dilaksanakan dalam 2 pertemuan, dan siklus II juga dilaksanakan 2 pertemuan.

Tes digunakan untuk memeroleh data tentang kemampuan siswa memahami teks bahasa Jerman, sedangkan data tentang aktivitas pembelajaran siswa selama tindakan dilakukan, diperoleh melalui lembar observasi guru dan lembar observasi siswa. Pada proses pengisian lembar observasi, semua indikator dari aktivitas yang diamati tercantum didalamnya. Pemberian tes tertulis dilaksanakan pada setiap akhir siklus. Berikut ini prosedur penilaian untuk setiap komponen yaitu:

a. Pilihan ganda (multiple choice) sebanyak 10 butir soal. Jawaban benar siswa memperoleh skor 1 dan jawaban salah mendapat skor 0. Skor maksimal yang dapat diperoleh siswa adalah 10 jika jawaban semua benar.

b. Menentukan jawaban benar salah (richtig-Falsch) yang terdiri atas 10 butir soal, jawaban siswa benar mendapat skor 1 dan jika salah mendapat skor 0 , jadi skor maksimal yang dapat diperoleh siswa adalah 10 jika semua jawaban benar.

c. Tes menjodohkan (Testspil) kalimat berjumlah 10 butir soal. Jika benar memperoleh skor 1 dan jika jawaban kurang tepat memperoleh skor 1 dan jawaban salah memperoleh skor 0. Jadi skor maksimal 10.

Dari penjelasan di atas dapat disimpulkan bahwa jumlah skor maksimal untuk tes kemampuan membaca siswa adalah 30. Penilaian hasil keseluruhan tes dalam penelitian ini mengacu pedoman yang digunakan oleh guru bidang studi bahasa Jerman MAN 1 Makassar dengan menggunakan rentang nilai 10 sampai 100 . (Purwanto: 2012, 102).

Teknik analisis data yang digunakan dalam penelitian ini terdiri atas dua yaitu secara kualitatif dan kuantitatif. Analisis data secara kualitatif ini digunakan untuk mengetahui peningkatan siswa dalam proses pembelajaran kemampuan membaca pada siklus I dan siklus II Sedangkan analisis data kuantitatif digunakan untuk mengetahui tingkat kemampuan siswa yang ditunjukkan dengan hasil dari tes membaca yang diberikan dari siklus I dan siklus II.

\section{HASIL DAN PEMBAHASAN}

Hasil penelitian telah diuraikan meliputi hasil tes, baik pada siklus I dan siklus II. Tes yang diberikan kepada siswa meliputi tes kemampuan membaca bahasa Jerman yang terdiri dari pilihan ganda, richtig-falsch dan tes menjodohkan. Proses penelitian kemampuan membaca dideskripsikan secara kualitatif. Sedangkan hasil penelitian dideskripsikan secara kuantitatif.Sistem penyajian data hasil kemampuan siswa mengemukakan tanggapan yang berupa angka disajikan dalam bentuk tabel, kemudian diuraikan makna dari laporan tabel tersebut. Selanjutnya, data nontes dideskripsikan dalam bentuk 
rangkaian kalimat.Hasil nontes yang dipaparkan pada siklus I dan siklus II meliputi hasil lembar observasi terhadap aktivitas siswa dan guru.untuk mencari peningkatan dalam pencarian hasil penelitian dan lebih teliti dalam pelaksanaannya, maka peneliti memusatkan pada satu kelas saja yaitu dilakukan di kelas XI IPA MAN 1 Makassar.

Pelaksanaan penelitian ini dimulai pada tanggal 6 Februari sampai 13 Maret 2017. Awal kegiatan dilakukan pada tanggal 4 Februari 2017, peneliti berkunjung ke sekolah MAN 1 Makassar untuk melihat bagaimana situasi proses pembelajaran berlangsung. Proses penerapan model pembelajarn Cooperative Script dalam kemampuan membaca bahasa Jerman siswa kelas XI IPA MAN 1 Makassar dilaksanakan dalam dua siklus melalui perencanaan yang telah ditetapkan. Masing-masing siklus terdiri atas tiga kali pertemuan dengan rincian dua kali pertemuan untuk pembelajaran dan satu kali pertemuan untuk evaluasi.

\section{Deskripsi Hasil Pertemuan Siklus I} Kemampuan Membaca melalui model Cooperative Script Pada Siswa Kelas XI IPA MAN 1 Makassar.

Adapun hasil tes membaca menunjukkan bahwa siswa kelas XI IPA 2 masih banyak belum mampu menjawab soalsoal dengan tepat baik pilihan ganda, benarsalah (richtig, falsch), dan tes menjodohkan. Hal tersebut dipicu karena kurangnya kosakata siswa. Siswa juga masih sulit membedakan artikel dan Personal Pronomen. Suasana kelas yang sangat ribut menyebabkan siswa yang lain kurang fokus menjawab soal-soal yang diberikan guru.

Berdasarkan data yang diperoleh dapat dsimpulkan bahwa jumlah siswa sebanyak 31 dari jumlah 33 siswa pada siklus I. Adapun nilai terendah yang didapatkan siswa dalam kemampuan membaca bahasa Jerman adalah 50 sedangkan siswa mendapatkan nilai tertinggi yaitu 87 .

Untuk menentukan rentangan (R) dan jumlah kelas interval jumlah peserta di kelas terdapat 31 siswa. Sedangkan kelas interval hasilnya mencapai 5,920 dibulatkan menjadi 6. Adapun rumus yang digunakan untuk mencari $\log$ tersebut yaitu $1+3,3 \log n$. $\log n$ yaitu $\log 31=1,49$, setelah hasil yang didapatkan jumlah kelas interval yaitu 6 selanjutnya untuk mencari rentangan digunakan rumus tertinggi (h) - rendah (l) sehingga hasil yang didapatkan besar rentangan yaitu $6,16=6$.

Diketahui bahwa dari jumlah 33 siswa kelas XI IPA 2, hanya siswa yang hadir hanya 31 terdapat 2 siswa atau $6,45 \%$ yang memeroleh nilai pada kelas interval dengan rentangan 49,5, 10 siswa atau $32,25 \%$ dan memeroleh nilai kelas interval 55,5, 9 siswa atau $29,03 \%$ yang memeroleh nilai pada kelas interval 67,5, 8 siswa atau 25,80\% dan memeroleh nilai kelas interval 67,5, 1 siswa atau 3,22\% yang memeroleh kelas interval $73,5,1$ siswa atau 3,22 yang memeroleh interval 79,5.

Berdasarkan uraian di atas dapat disimpulkan bahwa dari 31 siswa terdapat 10 siswa atau $32,25 \%$ yang memeroleh nilai kelas interval dengan rentangan 55,5, 1 siswa atau $3,22 \%$ yang memeroleh nilai kelas interval dengan rentangan 73,5, dan hanya 1 
siswa atau 3,22 yang memeroleh rentangan nilai kelas interval 79,5. Maka Persentase skor rata-rata siswa yang diperoleh pada siklus I adalah $64,72 \%$.

\section{Deskripsi Hasil pertemuan siklus II Kemampuan Membaca melalui Model Cooperative Script pada Siswa Kelas XI IPA MAN 1 Makassar.}

Evaluasi yang dilakukan siklus II dengan menerapkan model pembelajaran Cooperative Script dalam kemampuan membaca kelas XI IPA2. Evaluasi yang dilakukan selama proses pemberian tes dilaksanakan berlangsung lancar. Siswa sangat fokus dan tenang untuk mengerjakan tugas yang diberikan guru. Kerjasama antar pasangan cukup bagus. Pemahaman materi wacana yang diberikan pada siklus II cukup baik. Siswa bersemangat mencari kosakata yang merupakan hal baru yang diketahui.

Berdasarkan data yang diperoleh dalam kemampuan membaca bahasa Jerman siswa kelas XI IPA MAN 1 Makassar, dapat disimpulkan bahwa dari jumlah siswa 33 yang hadir hanya 30 di kelas. Adapun nilai terendah siswa kelas XI IPA 2 mendapat nilai 80, sedangkan nilai tertinggi yang dicapai oleh siswa adalah 97.

Kemudian untuk menentukan rentangan (R) dan jumlah kelas interval dari jumlah siswa di kelas XI IPA MAN 1 yaitu hanya 30 siswa dari 33 siswa. Sedangkan rumus yang digunakan untuk mencari jumlah kelas interval maka digunakan rumus yaitu 1+3,3 $\log 31$. Log n diartikan jumlah peserta yaitu $\log 30$ hasilnya didapatkan 1,477 dan setelah dijumlahkan maka hasil yang didapatkan kelas interval yaitu 5,87 dibulatkan menjadi 6. Setelah hasil yang didapatkan jumlah kelas interval selanjutnya, untuk rentangan digunakan rumus tertinggi (h) - rendah (l) maka hasil yang didapatkan 17. Hasil yang didapatkan 17 dibagi dengan kelas interval maka jumlah yang didapatkan besar rentangan (i) yaitu 2,83 dibulatkan menjadi 3.

Data frekuensi kemampuan membaca bahasa Jerman siswa kelas XI IPA 2 MAN 1 Makassar dari 33 jumlah siswa hanya terdapat 30 jumlah siswa yang hadir. Terdapat 1 siswa atau $3,33 \%$ yang memeroleh nilai pada kelas interval dengan rentangan 79,5, 1 siswa atau 3,33\% yang memeroleh nilai pada kelas interval dengan rentangan 92,5, 3 siswa atau $10 \%$ yang memeroleh nilai pada kelas interval dengan rentangan $85,5,2$ siswa atau $6,66 \%$ yang memeroleh nilai pada kelas interval dengan rentangan 88,5, 11 siswa atau 36,66\% memeroleh nilai pada kelas interval dari rentangan 91,5, 12 siswa atau 40 nila pada kelas interval yang diperoleh dengan rentangan 94,5.

Berdasarkan uraian diatas dapa disimpulkan bahwa dari 30 terdapat 12 siswa atau $40 \%$ yang memeroleh nilai pada kelas interval dengan rentangan 94,5 sedangkan hanya 1 siswa atau $3.33 \%$ yang memeroleh nilai kelas interval dengan rentangan 79,5. Hal ini menunjukkan bahwa penerapan model pembelajaran cooperative script dalam meningkatkan kemampuan membaca siswa kelas XI IPA2. Perolehan hasil tes kemampuan membaca dapat dilihat pada tabel diatas bahwa sebanyak 12 siswa yang mendapatkan nilai 96,66.

Berdasarkan penelitian yang telah dilaksanakan di kelas XI IPA MAN 1 
Makassar, hasil yang didapatkan sangat memuaskan bagi peneliti karena hanya dengan dua siklus saja. Peningkatan kemampuan membaca melalui model cooperative script.Penelitian ini dilaksanakan dalam dua siklus yaitu siklus I dan siklus II.Pada siklus I dilakukan 2 pertemuan dan siklus II juga 2 pertemuan.Setiap akhir pertemuan ke dua dilaksanakan evaluasi untuk siswa untuk mengetahui sejauh mana kemampuan membaca bahasa Jerman siswa kelas XI IPA2.Setiap pertemuan peneliti melakukan observasi bagi siswa dan guru.Pelaksanaan evaluasi, berlangsung dua kali yaitu 1 kali untuk siklus I dan 1 kali siklus II.

Pengamatan yang dilakukan peneliti selama proses pembelajaran baik siklus I dan siklus II dapat memberikan perubahan kepada siswa. Antusias siswa yang memerhatikan dan mengikuti penjelasan guru meningkat pada siklus II yaitu rata-rata (43,93\%) dibandingkan dengan siklus I hanya mendapatkan dengan persentase $(42,42 \%)$. Siswa juga mengalami peningkatan ketika mengemukakan pendapat tentang materi yang diberikan oleh guru yaitu $39,39 \%$ sedangkan siklus I hanya mendapatkan $34,84 \%$. Selain itu siswa juga aktif menanyakan hal-hal yang kurang dipahami dari materi diberikan guru mengalami peningkatan siklus II yaitu 51,51 $\%$. Siswa juga mengerjakan tugas tepat waktu siklus I mendapatkan nilai hanya 33,33\% dan meningkat pada siklus II yaitu 37,87\%. Siswa merespon positif (senang) terhadap metode yang diajarkan guru mengalami peningkatan yaitu $27,27 \%$ dibandingkan siklus I 25,75\% dan Siswa bersemangat mengikuti pelajaran hingga akhir juga mengalami peningkatan siklus II yaitu $42,42 \%$ dibandingkan siklus I yaitu $36,36 \%$

Pengamatan yang telah dilakukan peneliti terdapat 2 aktivitas persentase siswa yang menurun. Hal tersebut diduga karena selama proses pembelajaran siswa tidak memerhatikan penjelasan guru. Siswa lebih memilih aktivitas lain. Jadi, perhatian siswa tidak fokus terhadap pembelajaran. Sehingga siswa mengerjakan soal-soal latihan yang diberikan tidak mendapat nilai yang memuaskan. Sedangkan siswa yang membaca wacana/teks dengan tepat juga menurun dari persentase siklus II. Hal tersebut disebabkan karena kurangnya latihan-latihan membaca teks bahasa Jerman. Pelafalan bacaan yang tidak sesuai dengan huruf yang diucapkan. Dilihat persentase siswa yang mendengarkan penjelasan guru dengan baik menurun dari persentase siklus II mendapat nilai 33,33\% dibandingkan dengan siklus I yaitu $34,84 \%$. Siswa juga membaca selintas dengan cepat wanana/teks tentang essen und trinken dengan lafal yang tepat menurun dari persentase siklus II mendapatkan nilai $16,66 \%$ dibandingkan siklus I yaitu $18,18 \%$.

Hasil belajar siswa juga mengalami peningkatan yakni dari $64,72 \%$ pada siklus II meningkat menjadi 92,99\%. Dengan demikian berdasarkan data hasil penelitian di atas menunjukan bahwa penerapan model pembelajaranCooperative Script dalam kemampuan membaca bahasa Jerman siswa kelas XI MAN 1 Makassar dapat dikatakan "Berhasil". 


\section{KESIMPULAN}

Berdasarkan hasil penelitian dan pembahasan yang dilakukan maka disimpulkan bahwa :

1. Perencanaan yang dilakukan dengan model pembelajaran Cooperative Script dilihat dari beberapa aspek melalui rencana pelaksanaan pembelajaran (RPP) juga mempersiapkan alat yang berupa buku Deutsch ist einfach dan kamus. Mempersiapkan tes instrument kemampuan membaca dan lembar observasi siswa dan guru.

2. Proses kemampuan membaca teks bahasa Jerman siswa kelas XI IPA 2 MAN 1 Makassar melalui model Cooperative Script mengalami peningkatan pada siklus II. Siswa mengalami perubahan perilaku dalam pembelajaran ke arah positif. Selama proses pembelajaran keadaan kelas cukup kondusif serta siswa tampak serius mendiskusikan teks/ dialog yang diberikan oleh guru dan siswa aktif menjelaskan maksud dari bacaan yang dipahami bersama pasangannya.

3. Hasil tes kemampuan membaca Bahasa Jerman siswa kelas XI IPA2 dengan menggunakan model Cooperative Script menunjukkan, bahwa nilai rata-rata pada siklus I yaitu $64,72 \%$ sedangkan nilai rata-rata pada siklus II 92,99\% dan dinyatakan berhasil. Adapun perbandingan skor rentangan yang diperoleh antara sikus I dan siklus II yaitu 28,27 .

\section{DAFTAR PUSTAKA}

Andayani. 2015. Problema dan Aksioma dalam Metodologi Pembelajaran
Bahasa Indonesia. Yogyakarta: Deepublish.

Dalman. 2014. Keterampilan Menulis. Jakarta: Rajawali Pers.

Dimyati dan Mudjiono. 2005. Pengelolaan Pembelajaran. Yogykarta: Deepublish.

Djiwandono, Soenardi. 2008. Tes Bahasa Pegangan bagi Pengajar Bahasa.Jakarta : Indeks.

Haling, Abdul. 2007. Belajar dan Pembelajaran. Makassar: Badan Penerbit UNM.

Hamra Arifuddin \& Eny Syatriana.2010.Model

pembelajaran membaca pemahaman bahasa inggris sekolah menengah. Makassar: Badan penerbit Universitas Negeri.

Hammoud,Antje und Ratzki.2002. Fremdsparche Deutsch Kooperative Lernen. Donnauwörth: Heuber verlag.

Huda, Miftahul. 2014. Cooperative Learning. Yogyakarta: Pustaka Pelajar.

Huda, Miftahul. 2014. Model-Model Pengajaran dan Pembelajaran. Yogyakarta:Pustaka Belajar.

Isjoni. 2014. Cooperative Learning. Bandung: Alfabeta.

Iskandarwassid, Sunendar Dadang. 2011. Strategi Pembelajaran Bahasa. Bandung: PT Remaja Rosdakarya.

Jihad dan Haris.2012.Evaluasi Pembelajaran. Yogyakarta: Multi Pressindo. 
Knirk dan Gustafson. 2005. Pengelolaan Pembelajaran. Yogykarta: Deepublish.

Muslim, Rismayanti .2012. Hubungan Penguasaan Kosakata dengan Kemampuan Membaca Memahami Siswa Kelas XI IPA SMA Negeri 2 Bontotiro Kabupaten Bulukumba. Skripsi. Fakultas Bahasa dan Sastra. Universitas Negeri Makassar.

Murniati dan Usman, 2009. Implementasi Menajemen Stratejik. Bandung: Angkasa.

Nurmiati, N., \& Mantasiah, R. 2017. Keefektifan Penggunaan Metode Pembelajaran Tutor Sebaya (PeerTeaching) Dalam Kemampuan Membaca Memahami Bahasa Jerman Siswa Kelas XI IPA SMA Negeri 1 Bontonompo Kabupaten Gowa. Eralingua: Jurnal Pendidikan Bahasa Asing dan Sastra, 1(1).

Nurrobikha dan Burhan Asmawati, 2015.Buku Ajar Konsep

Kebidanan. Yogyakarta:

Deepublish.

Purwanto, Ngalim. 2012. Prinsip - Prinsip dan Teknik Evaluasi Pengajaran. Bandung : Rosda.

Rofa'ah. 2016. Pentingnya Kompetensi Guru dalam Kegiatan Pembelajaran. Yogyakarta: Deepublish.

Rusman. 2011. Model-Model Pembelajaran Mengembangkan Profesionalisme Guru. Jakarta:Rajawali Pers.

Saddhono, Kundharu dan Slamet.2014. Pembelajaran

Keterampilan
Berbahasa Indonesia.Edisi 2. Yogyakarta: Graha Ilmu.

Saifuddin, 2014.Pengelolaan Pembelajaran. Yogyakarta : Deepublish.

Sanjaya, Wina. 2013. Penelitian Tindakan Kelas. Jakarta : Kencana

Sina, Peter Garlans. 2015. The Real Spirit Of Learning. Yogyakarta: Garudhaca.

Somadayo, Samsu. 2011. Strategi dan Teknik Pembelajaran Membaca. Yogyakarta: Graha Ilmu.

Sugiarni.2008. Kemampuan Membaca Memahami Bahasa Jerman Siswa SMA Negeri 3 Makassar.Makassar :Skripsi FBS UNM.

Suprihanto dkk. 2003. Perilaku Organisasional. Jakarta: PT Rineka Cipta

Suprijono, Agus. 2014. Cooperative Learning. Yogyakarta: Pustaka Pelajar.

Syafaruddin. 2012. Pendidikan dan Pemberdayaan Masyarakat. Jakarta: Perdana Mulya

Tarigan, Henry Guntur. 2008. Pembelajaran Membaca Berbasis pendidikan Karakter. Bandung: PT Refika Aditama.

Widyastuty, Hilda. 2013. Kemampuan Membaca Memahami wacana Bahasa Jerman Siswa Kelas XI IPS SMA Negeri 1 Makassar.Makasssar.Skripsi.Faku ltas Bahasa dan Sastra.Universitas Negeri Makassar.

Winataputra, Udin. 2001. Penelitian Tindakan Kelas. Jakarta: Laksana. 